\title{
A new composite cathode for intermediate temperature solid oxide fuel cells with zirconia- based electrolytes
}

\author{
Cuijuan Zhang, Kevin Huang
}

Department of Mechanical Engineering, University of South Carolina, Columbia, SC USA 29208

HUANG46@cec.sc.edu

\begin{abstract}
Improving the electrocatalytic activity of electrode materials is vitally important to achieve practically meaningful performance for intermediate temperature solid oxide fuel cells (ITSOFCs). The present work develops a composite cathode consisting of an electronic conductor Sr-doped $\mathrm{LaMnO}_{3}$ (LSM) and an ionic conductor Y- and Ce- co-doped $\mathrm{Bi}_{2} \mathrm{O}_{3}$ (BYC7). BYC7 is an excellent oxide-ion conductor, exhibiting a high and stable ionic conductivity of $0.008 \mathrm{~S} \mathrm{~cm}^{-1}$ at $500{ }^{\circ} \mathrm{C}$. The polarization resistance of LSM-BYC7 cathode in a symmetrical cell with doped $\mathrm{ZrO}_{2}$ as electrolyte varies from 5.76 at $500{ }^{\circ} \mathrm{C}$ to $0.25 \Omega \mathrm{cm}^{2}$ at $650{ }^{\circ} \mathrm{C}$. The surface diffusion and charge transfer at the triple phase boundaries are the rate determining steps based on the dependence of polarization resistance on partial pressure of oxygen. The maximum power density of a $\mathrm{ZrO}_{2}$-based anode-supported cell with LSM-BYC7 composite cathode is 56.4, 154.6, 327.9 , and $451.0 \mathrm{~mW} \mathrm{~cm}{ }^{-2}$ at $500,550,600$, and $650{ }^{\circ} \mathrm{C}$ respectively. AC impedance analysis reveals that the performance of IT-SOFC prepared in this study is actually limited by the anode, not by LSM-BYC7 cathode.
\end{abstract}

Keywords: Intermediate temperature solid oxide fuel cells, composite cathode, bismuth oxide, lanthanum manganese oxide, AC impedance 


\section{Introduction}

Solid oxide fuel cells (SOFCs) as an efficient, fuel flexible, and environmentally clean power generator have been developed towards a commercial product for many decades [1]. The major barriers impeding the commercialization of SOFCs are high cost and poor reliability. To overcome these barriers, it is necessary to reduce the operating temperature from the current high temperatures $\left(\geq 750{ }^{\circ} \mathrm{C}\right)$ to intermediate temperatures $\left(\mathrm{IT}, \leq 650{ }^{\circ} \mathrm{C}\right)[2,3]$. This effort can be realized by reducing the thickness of the state-of-the-art electrolytes such as $\mathrm{Y}_{2} \mathrm{O}_{3}$-doped $\mathrm{ZrO}_{2}$ (YSZ), employing high-conductivity electrolytes and catalytically active electrode materials. For example, electrolytes such as rare-earth (RE)-doped $\mathrm{CeO}_{2}, \mathrm{Sr}$ - and $\mathrm{Mg}$-doped $\mathrm{LaGaO}_{3}(\mathrm{LSGM})$, doped $\mathrm{Bi}_{2} \mathrm{O}_{3}$ and $\mathrm{Sc}$-doped $\mathrm{ZrO}_{2}$ [3-8] have been extensively studied to lower the operating temperature to $\leq 600{ }^{\circ} \mathrm{C}$. Mixed oxide-ion and electron conductors (MIECs) such as $\operatorname{La}_{1-\mathrm{x}} \mathrm{Sr}_{\mathrm{x}} \mathrm{Co}_{1 \text { - }}$ ${ }_{y} \mathrm{Fe}_{\mathrm{y}} \mathrm{O}_{3-\delta}, \mathrm{Sm}_{1-\mathrm{x}} \mathrm{Sr}_{\mathrm{x}} \mathrm{CoO}_{3-\delta}, \mathrm{Ba}_{1-\mathrm{x}} \mathrm{Sr}_{\mathrm{x}} \mathrm{Co}_{1-\mathrm{y}} \mathrm{Fe}_{\mathrm{y}} \mathrm{O}_{3-\delta}, \mathrm{Ln}$ ( $\left.\mathrm{Ln}=\mathrm{La}, \mathrm{Sm}, \mathrm{Gd}, \mathrm{Nd}\right) \mathrm{BaCo}_{2} \mathrm{O}_{5+\delta}$, and $\mathrm{La}_{2} \mathrm{NiO}_{4}$, etc. [2, 9-11] have been broadly investigated as oxygen reduction reaction (ORR) active cathode materials for reduced-temperature SOFCs.

From the perspective of commercial applications, SOFCs based on $\mathrm{CeO}_{2}$-based and $\mathrm{CeO}_{2}$ based/ $\mathrm{Bi}_{2} \mathrm{O}_{3}$-based bilayer electrolytes are less attractive due to their intrinsically high electronic conduction and mechanical issues upon exposure to reducing atmospheres although they show excellent performance in lab-scale button cells $[3,11]$. The LSGM-based SOFCs face the same problems given its high cost, high chemical reactivity with conventional electrode materials, and low mechanical strength $[6,12,13]$. Therefore, $\mathrm{ZrO}_{2}$-based SOFCs still remain the main stream of commercial development. Among all $\mathrm{ZrO}_{2}$-based electrolytes, Sc-and Ce- co-doped $\mathrm{ZrO}_{2}$ (SCSZ) stands out to be a promising IT-electrolyte due to its high, pure and stable oxide-ion 
conductivity over a wide range of oxygen partial pressure, excellent chemical stability, high mechanical strength and good compatibility with nickel metal $[5,8]$. However, the catalytically active cathode materials aforementioned cannot be directly used with SCSZ electrolyte because of their high propensity to react with $\mathrm{ZrO}_{2}$ during fabrication and/or operation, forming lowconductivity phases such as $\mathrm{La}_{2} \mathrm{Zr}_{2} \mathrm{O}_{7}, \mathrm{BaZrO}_{3}, \mathrm{SrZrO}_{3}$ and thus deteriorating the performance $[2$, 10]. A thin buffer layer of doped $\mathrm{CeO}_{2}$ is needed between cathode and electrolyte in order to prevent those detrimental reactions [14-16], which inevitably makes the fabrication processing complex and costly.

Sr-doped $\mathrm{LaMnO}_{3}(\mathrm{LSM})$ and its composite with YSZ are the common cathodes of choice for high-temperature $\mathrm{ZrO}_{2}$-based SOFCs because of its excellent chemical and mechanical compatibility with $\mathrm{ZrO}_{2}$-based electrolyte [17]. However, their performance is very poor at reduced temperatures, the fundamental reason of which is rooted in the low ionic conductivity in YSZ and negligible ionic conductivity in LSM [17]. By switching YSZ with Gd-doped $\mathrm{CeO}_{2}$ (GDC), Murray and Barnett [18] showed that the area specific resistance (ASR) at $700{ }^{\circ} \mathrm{C}$ was reduced from $7.28 \Omega \mathrm{cm}^{2}$ for pure LSM to $2.49 \Omega \mathrm{cm}^{2}$ for LSM-YSZ and further to $0.75 \Omega \mathrm{cm}^{2}$ for LSM-GDC cathode. While the reduction in ASR by adding an ionic conducting phase into LSM is undoubtedly due to the increased triple phase boundaries (TPBs), the lowest ASR exhibited by LSM-GDC is conceivably attributed to the one-order of magnitude higher ionic conductivity of GDC than YSZ (e.g. $3.1 \times 10^{-2}$ vs. $3.2 \times 10^{-3} \mathrm{~S} \mathrm{~cm}^{-1} @ 600{ }^{\circ} \mathrm{C}$ and $7.9 \times 10^{-2}$ vs. 1.8 $\times 10^{-2} \mathrm{~S} \mathrm{~cm}^{-1} @ 750{ }^{\circ} \mathrm{C}$ ) [19]. In other words, the electrical conductivity of the ionic conducting phase critically determines the ORR performance of a composite cathode.

Stabilized $\mathrm{Bi}_{2} \mathrm{O}_{3}$ exhibits the highest ionic conductivity among all the known oxide-ion conductors $[3,20]$. For example, the electrical conductivity of $20 \%$ Er-stabilized $\mathrm{Bi}_{2} \mathrm{O}_{3}(\mathrm{ESB})$ is 
0.41 and $0.021 \mathrm{~S} \mathrm{~cm}^{-1}$ at 800 and $500{ }^{\circ} \mathrm{C}$, respectively [21]. Wachsman group [3, 22] reported a much reduced cathodic polarization resistance at intermediate temperatures by adding ESB into LSM. The ASR of the LSM-ESB cathode on GDC electrolyte is 10.56, 3.31, 1.11, 0.44, and 0.19 $\Omega \mathrm{cm}^{2}$ at $500,550,600,650$, and $700{ }^{\circ} \mathrm{C}$, respectively. The maximum power density of a single SOFC using such cathode and ESB/GDC bilayer electrolyte reached $1,013 \mathrm{~mW} \mathrm{~cm}{ }^{-2}$ at $650{ }^{\circ} \mathrm{C}$ [22]. The follow-up work also confirmed improved intermediate-temperature performance with LSM- $\mathrm{Bi}_{2} \mathrm{O}_{3}$ composite cathode [23-29]. Li et al. reported that the 50\%ESB-infiltrated LSM yielded ASR of 0.22 and $0.48 \Omega \mathrm{cm}^{2}$ at 700 and $650{ }^{\circ} \mathrm{C}, \sim 35 \times$ lower than those of pure LSM [26]. Jiang et al. showed that the ASR can be significantly reduced by infiltrating the LSM scaffold with yttrium-stabilized $\mathrm{Bi}_{2} \mathrm{O}_{3}$ (YSB), i.e. decreasing from $85.2 \Omega \mathrm{cm}^{2}$ for pure LSM to $4.95 \Omega$ $\mathrm{cm}^{2}$ for 20\% YSB-infiltrated LSM and further to $1.08 \Omega \mathrm{cm}^{2}$ for $50 \%$-YSB infiltrated LSM [25] at $600{ }^{\circ} \mathrm{C}$. The problem with $\mathrm{LSM}-\mathrm{Bi}_{2} \mathrm{O}_{3}$ composite cathodes is, however, the poor structural stability of ESB $\left(500{ }^{\circ} \mathrm{C}\right)$ and YSB $\left(500-650{ }^{\circ} \mathrm{C}\right)$ at lower temperatures where oxygen vacancies tend to become ordered $\left(500{ }^{\circ} \mathrm{C}\right)$ or phase transformation from cubic to rhombohedral $(600-650$ $\left.{ }^{\circ} \mathrm{C}\right)$ takes place, both of which considerably limit the mobility of oxide-ions [30-33]. For example, the electrical conductivity of ESB was decreased by $\sim 25 \times$ after annealing at $500{ }^{\circ} \mathrm{C}$ for $100 \mathrm{~h}[31$, 34]. In an effort to alleviate the conductivity degradation, Huang et al. [32] reported that by adding an appropriate amount of $\mathrm{CeO}_{2}$ into YSB can inhibit the phase transformation and thus retaining electrical conductivity. Such a Ce- and Y-co-doped $\mathrm{Bi}_{2} \mathrm{O}_{3}$ (BYC) showed no sign of degradation in electrical conductivity for $\sim 400 \mathrm{~h}$ at $600{ }^{\circ} \mathrm{C}$, whereas that of the Y-singly doped $\mathrm{Bi}_{2} \mathrm{O}_{3}$ declined by about one order of magnitude. Therefore, it is interesting to explore BYC as the ionic conducting phase in LSM-based composite cathodes for $\mathrm{ZrO}_{2}$-based IT-SOFCs. 
In the present study, we report the performance of LSM-BYC composite as an IT-cathode for SOFCs. The results show that such a composite cathode exhibits competitive and stable electrocatalytic activity for ORR at intermediate temperatures and can be a promising cathode material for IT-SOFCs.

\section{Experimental}

\subsection{Materials synthesis}

The $\left(\mathrm{Bi}_{0.75} \mathrm{Y}_{0.25}\right)_{0.93} \mathrm{Ce}_{0.07} \mathrm{O}_{1.5 \pm \delta}(\mathrm{BYC} 7)$ and $\mathrm{La}_{0.8} \mathrm{Sr}_{0.2} \mathrm{MnO}_{3}$ (LSM) powders were prepared by citric acid-nitrate method. Details on the synthesis can be found in our recent report [35]. Briefly, stoichiometric amount of metal nitrate precursors and citric acid were dissolved into a diluted nitric acid solution with a volume ratio of concentrated nitric acid to deionized (DI) water at 1:9. The molar ratio of citric acid to total metal ions is $1.5: 1$. The solution was heated on a hot plate until auto-combustion. The porous powders were ground and calcined at $700{ }^{\circ} \mathrm{C}$ for $4 \mathrm{~h}$. The LSM powders were prepared in the similar way except that the molar ratio of citric acid to total metal ions was 2:1 and the $\mathrm{pH}$ of the solution was adjusted to $\sim 6$ with ammonia (28-30\%). The combusted powder was calcined at $900{ }^{\circ} \mathrm{C}$ for $5 \mathrm{~h}$.

Part of the BYC7 powders were then pressed into pellets and sintered at $1100{ }^{\circ} \mathrm{C}$ for $5 \mathrm{~h}$ to obtain dense samples for electrical conductivity measurement. Platinum paste and wire were used as current collector by attaching to both sides and curing at $900{ }^{\circ} \mathrm{C}$ for $0.5 \mathrm{~h}$. For comparison, ESB powder was also prepared with similar method and dense samples were obtained after sintering at $900{ }^{\circ} \mathrm{C}$ for $5 \mathrm{~h}$.

\subsection{Fabrication of symmetrical cells and anode-supported single cell}

The performance of composite cathode LSM-BYC7 was examined in symmetrical cell and single cell with $\left(\mathrm{ZrO}_{2}\right)_{0.89}\left(\mathrm{Sc}_{2} \mathrm{O}_{3}\right)_{0.1}\left(\mathrm{CeO}_{2}\right)_{0.01}$ (SCSZ, Daiichi Kigenso Kagaku Co. Ltd., Japan) 
as electrolyte. Details on the fabrication can also be found in Ref. [35]. In brief, the cathode ink composed of LSM, BYC7 and V-006A at a weight ratio of 40:60:100 was screen-printed onto both sides of the SCSZ electrolyte symmetrically, followed by firing at $800{ }^{\circ} \mathrm{C}$ for $2 \mathrm{~h}$. The anode-supported cell was prepared by co-pressing and co-sintering of Ni-SCSZ anode and SCSZ electrolyte bilayer, followed by screen-printing cathode ink. The anode support, 70wt.\%NiO$30 \mathrm{wt} . \% \mathrm{SCSZ}$ with $2 \%$ carbon as pore former, was pressed into pellets of 1 " in diameter. Then the SCSZ powder was distributed uniformly on the top of the green anode substrate, followed by uniaxial pressing to form an electrolyte/anode bi-layer structure. The resultant pellets were cosintered at $1300{ }^{\circ} \mathrm{C}$ for $4 \mathrm{~h}$ and finally polished down to $\sim 400 \mu \mathrm{m}$. The LSM-BYC7 cathode slurry was then screen-printed onto the surface of SCSZ and finally calcined to form the single cell. The effective area of the electrode is $0.712 \mathrm{~cm}^{2}$. The silver mesh and paste as current collector were applied onto both sides and cured at $550{ }^{\circ} \mathrm{C}$ for $0.5 \mathrm{~h}$.

\subsection{Characterization}

The electrical conductivity of BYC7, polarization resistance of LSM-BYC7 in symmetrical cell and performance of anode-supported single cell were evaluated with a Solartron electrochemical station consisting of 1470 multichannel potentiostat and 1255B frequency response analyzer. The symmetrical cell was also tested in a range of oxygen partial pressure $\left(p\left(\mathrm{O}_{2}\right)\right)$ and temperature $\left(400-650{ }^{\circ} \mathrm{C}\right)$; the former was achieved by mixing pure $\mathrm{N}_{2}$ and $\mathrm{O}_{2}$ in an appropriate ratio controlled by mass flow controller. The total flowing rate of the mixture was fixed at $100 \mathrm{sccm}$. For single cell testing, a humidified $\left(\sim 3 \% \mathrm{H}_{2} \mathrm{O}\right)$ hydrogen flow at $50 \mathrm{sccm}$ and stagnant air were used as fuel and oxidant, respectively. For all the electrochemical impedance measurements, the frequency was swept in the range of $10^{6}-0.01 \mathrm{~Hz}$ with a perturbation $\mathrm{AC}$ amplitude of $10 \mathrm{mV}$. The obtained spectra were analyzed by ZSimpWin software. 
To examine the stability, BYC7 dense pellets with and without Pt paste on both sides was annealed at $500{ }^{\circ} \mathrm{C}$ for $100 \mathrm{~h}$ and X-ray diffraction (XRD) was performed on the surface of sample. To evaluate the chemical compatibility between LSM and BYC7, the two powders were mixed with a weight ratio of 40:60, pressed into pellets, calcined at $800{ }^{\circ} \mathrm{C}$ for $2 \mathrm{~h}$ and then annealed at $500{ }^{\circ} \mathrm{C}$ for $100 \mathrm{~h}$ in air, followed by XRD examination. The phase composition of fresh BYC7 and ESB was also checked by XRD. All the XRD runs were carried out on a Rigaku Miniflex II X-ray powder diffractometer equipped with a $\mathrm{Cu} \mathrm{K} \alpha$ radiation over the $2 \theta$ range of 20-70 ${ }^{\circ}$. The crystal structure of the fresh BYC7 and ESB were refined by the Rietveld method with FullProf software [36]. The microstructure of the fuel cell was observed by a field-emission scanning electron microscopy (FESEM, Zeiss Ultra plus). The atomic ratio of BYC7 sample was analyzed by energy dispersive spectroscopy (EDS) unit equipped with the FESEM.

\section{Results and Discussion}

\subsection{Structural characteristics and electrical conductivity of BYC7}

The atomic ratio of $\mathrm{Bi}: \mathrm{Y}: \mathrm{Ce}$ in BYC7 samples analyzed by EDS is 0.70:0.47:0.068, which is in excellent agreement with the nominal composition of 0.6975:0.465:0.07 within experimental error. The X-ray diffraction pattern of BYC7, along with ESB, was refined with Rietveld method; the results are shown in Fig. 1. Both materials can be well refined into a cubic fluorite structure with space group of Fm-3m, suggesting that the high-temperature $\delta-\mathrm{Bi}_{2} \mathrm{O}_{3}$ cubic phase has been stabilized to room temperature by $\mathrm{Ce}$ - and Y-co-doping. The lattice parameter is 5.495 and 5.504 Å for BYC7 and ESB, respectively. 

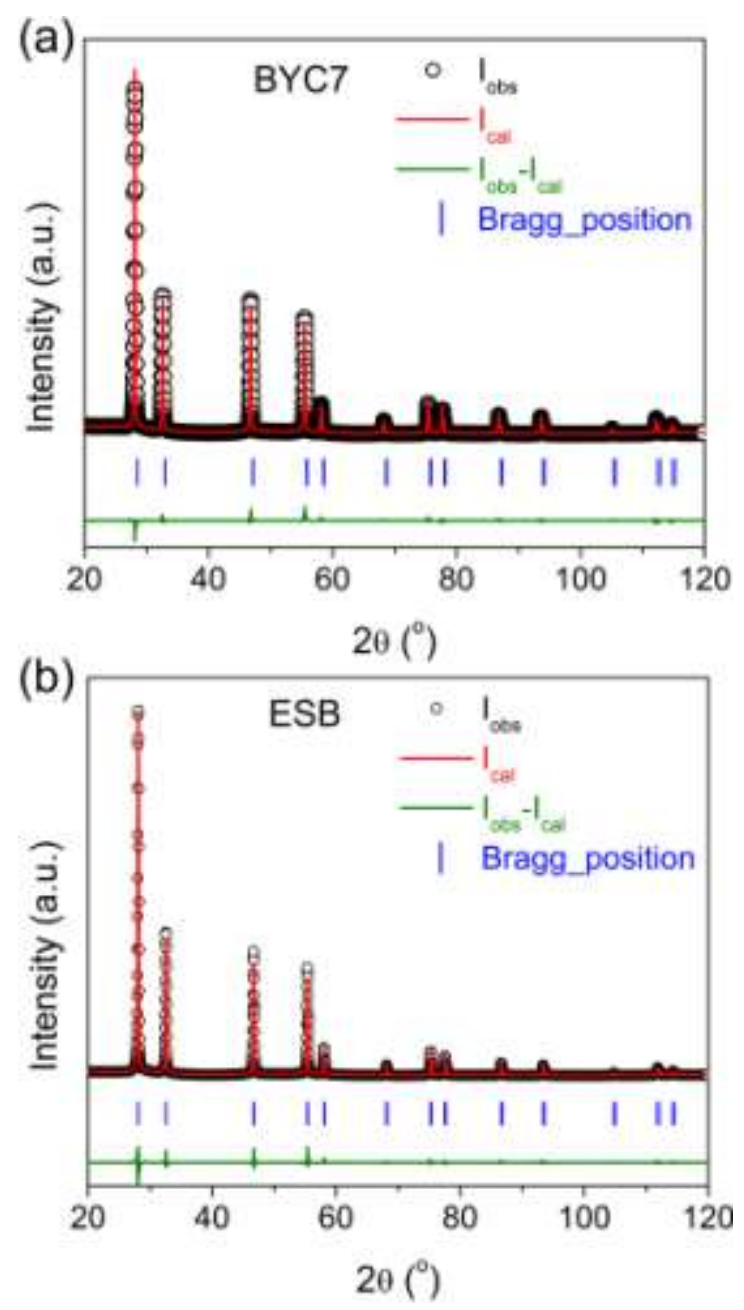

Fig. 1. XRD patterns and corresponding Rietveld refinement results of (a) BYC7 $\left(\mathrm{R}_{\mathrm{p}}=8.67 \%\right.$, $\mathrm{R}_{\mathrm{wp}}=8.23 \%$, ) and (b) $\operatorname{ESB}\left(\mathrm{R}_{\mathrm{p}}=10.2 \%, \mathrm{R}_{\mathrm{wp}}=9.75 \%\right)$.

The electrical conductivity of BYC7 and ESB measured by AC-impedance with Pt as current collector is shown in Fig. $2 \mathrm{a}$ as an Arrhenius plot. The apparent activation energy $\left(E_{a}\right)$ for BYC7 is $\sim 1.05 \mathrm{eV}$ in the temperature range of $400-650{ }^{\circ} \mathrm{C}$, which is in accordance with the reported value for other $\mathrm{Bi}_{2} \mathrm{O}_{3}$-based materials $[31,37]$. The electrical conductivity of $\mathrm{BYC} 7$ is 0.008 , $0.017,0.034,0.059 \mathrm{~S} \mathrm{~cm}^{-1}$ at $500,550,600$, and $650{ }^{\circ} \mathrm{C}$, respectively, which is higher than that of classical electrolytes such as doped $\mathrm{LaGaO}_{3} \quad\left(0.026 \quad \mathrm{~S} \quad \mathrm{~cm}^{-1} @ 595 \quad{ }^{\circ} \mathrm{C}\right.$ for $\left.\mathrm{La}_{0.8} \mathrm{Sr}_{0.2} \mathrm{Ga}_{0.83} \mathrm{Mg}_{0.17} \mathrm{O}_{3-\delta}\right)$ [7], doped $\mathrm{CeO}_{2}\left(\sim 0.032 \mathrm{~S} \mathrm{~cm}^{-1} @ 600{ }^{\circ} \mathrm{C}\right.$ for $\left.\mathrm{Ce}_{0.8} \mathrm{Gd}_{0.2} \mathrm{O}_{2-\delta}\right)$ [19]. The electrical conductivity of ESB is $0.025 \mathrm{~S} \mathrm{~cm}^{-1}$ at $500{ }^{\circ} \mathrm{C}$ and the $E_{a}$ value is $1.21 \pm 0.03 \mathrm{eV}$ over 
the temperature range of $400-650{ }^{\circ} \mathrm{C}$, consistent with the reported $0.021 \mathrm{~S} \mathrm{~cm}^{-1}[21]$ and $1.235 \pm$ $0.009 \mathrm{eV}[31]$.

The time-dependent conductivity data of Fig. $2 \mathrm{~b}$ show that the initial electrical conductivity of BYC7 is lower than that of ESB. However, the latter rapidly decreases by $\sim 18 \times$ over a period of $100 \mathrm{~h}$, similar with reported results $[30,31]$. Meanwhile, BYC7 remains stable. The XRD analysis of Fig. 2c on the post-test samples reveals no noticeable structural changes for both BYC7 and ESB. The stabilization of BYC7 conductivity has been previously reported to benefit from the inhibition of oxygen-vacancy-ordering related phase transformation [32]. The fact that no structural change but conductivity decay is observed for ESB in Fig. 2b suggests that oxygen vacancies become gradually ordered at $500{ }^{\circ} \mathrm{C}[30,33,34,38]$, which cannot be explicitly unveiled by XRD. The Ce-doping in BYC is effective to stop oxygen vacancies ordering at intermediate temperatures, which is highly desirable for IT-SOFCs.

Another finding from Fig. $2 \mathrm{c}$ is the appearance of $\mathrm{Bi}_{2} \mathrm{Pt}_{2} \mathrm{O}_{7}$ in both $\mathrm{BYC} 7$ and ESB after testing, indicating possible reaction between $\mathrm{Bi}_{2} \mathrm{O}_{3}$ and $\mathrm{Pt}$ at $500{ }^{\circ} \mathrm{C}$ over a long period of time. Its influence on electrical conductivity is not fully clear at this point, but $\mathrm{Bi}_{2} \mathrm{Ru}_{2} \mathrm{O}_{7}$ is known to have high electrical conductivity $\left(300 \mathrm{~S} \mathrm{~cm}^{-1}\right)$ at $500-700{ }^{\circ} \mathrm{C}$ [39] and it has been used as a cathode for SOFCs $[39,40]$. The observed $\mathrm{Bi}_{2} \mathrm{Pt}_{2} \mathrm{O}_{7}$ probably offers the functionality. Overall, it is unlikely that $\mathrm{Bi}_{2} \mathrm{Pt}_{2} \mathrm{O}_{7}$ is the reason for the observed conductivity degradation in ESB. 

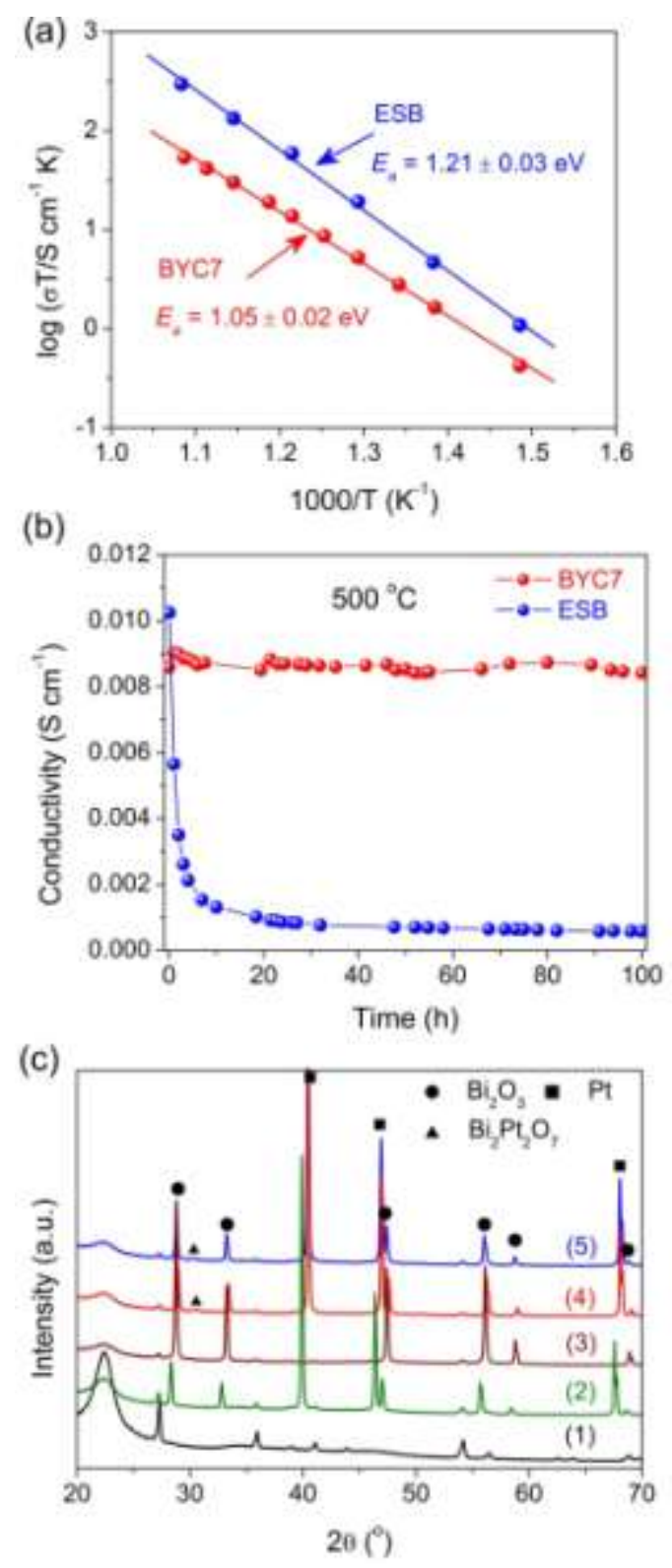

Fig. 2. (a) Arrhenius plot of electrical conductivity of BYC7 and ESB in air with Pt as current collector. (b) Evolution of electrical conductivity of BYC7 and ESB with time at $500{ }^{\circ} \mathrm{C}$ in air with Pt as current collector. (c) XRD of (1) sample holder for XRD test, (2) $900{ }^{\circ} \mathrm{C}-0.5 \mathrm{~h}$ calcined BYC7 pellet with Pt paste on both sides, (3) BYC7 samples annealed at $500{ }^{\circ} \mathrm{C}$ for $100 \mathrm{~h}$ in air, (4) BYC7 and (5) ESB pellets after electrical conductivity test at $500{ }^{\circ} \mathrm{C}$ for $100 \mathrm{~h}$ with Pt as current collector.

\subsection{Electrochemical performance of symmetrical cell}

The superior electrical conductivity and structural stability suggests that BYC7 can be an excellent candidate for ion-conducting phase in the composite cathode. The impedance spectra of 
symmetrical cell with LSM-BYC7 composite as electrode were measured in a range of $p\left(\mathrm{O}_{2}\right)$ (0.05-0.50 atm) and $\mathrm{T}\left(400-650{ }^{\circ} \mathrm{C}\right)$. For the impedance spectra at lower temperatures of 400 and $450{ }^{\circ} \mathrm{C}$, the grain-boundary contribution of the SCSZ electrolyte appeared at high frequencies and can be modeled by a $\left(\mathrm{R}_{\mathrm{gb}} \mathrm{Q}_{\mathrm{gb}}\right)$ parallel sub-circuit. For the spectra at low frequencies, two $\left(\mathrm{R}_{\mathrm{i}} \mathrm{Q}_{\mathrm{i}}\right)\left(\mathrm{i}=1\right.$, 2) parallel sub-circuits can be used, where $\mathrm{R}_{\mathrm{i}}$ and $\mathrm{Q}_{i}$ represent resistance and constant phase element, respectively, related to the electrode processes. The intercept of the impedance spectra with the $\mathrm{X}$-axis at high frequency, modeled as $\mathrm{R}_{0}$, is mainly contributed from resistance of SCSZ electrolyte, with minor contributions from the LSM-BYC7 electrode, interfaces of electrolyte/electrode and electrode/Ag. Figure 3a presents the spectra at $550{ }^{\circ} \mathrm{C}$ at different $p\left(\mathrm{O}_{2}\right)$, along with the fitting results. A good agreement is achieved between the experimental data and the fitting results. The total electrode ASR is the summation of $R_{1}$ and $R_{2}$.

In general, an ORR process at the cathode is a complex process, which may consist of several elementary steps that show different dependence on $p\left(\mathrm{O}_{2}\right)$, i.e., different $\mathrm{m}$ values in the relationship of $R_{i}=K p\left(O_{2}\right)^{-m_{i}}$ [41]. According to the model proposed by Heuveln and Bouwmeester [41], the ORR process includes: dissociative adsorption $\left(O_{2(g)} \leftrightarrow 2 O_{a d}\right)$, charge transfer $\left(O_{a d}+e^{\prime} \leftrightarrow O_{a d}^{-}\right)$, surface diffusion $\left(O_{a d}^{-} \leftrightarrow O_{T P B}^{-}\right)$, charge transfer at TPBs $\left(O_{T P B}^{-}+\right.$ $\left.e^{\prime} \leftrightarrow O_{T P B}^{2-}\right)$, and ion incorporation from TPBs to the electrolyte $\left(O_{T P B}^{2-}+V_{O, \text { electrolyte }}^{\prime \prime} \leftrightarrow\right.$ $O_{O, \text { electrolyte }}^{\times}$. The corresponding $\mathrm{m}$ values are $1,0.375,0.25,0.125$, and 0 , respectively. The capacitance (C), which is independent of sample geometry and is a good indicator of the cathodic process, can be calculated by [42]

$$
C=\frac{(R Q)^{1 / n}}{R}
$$



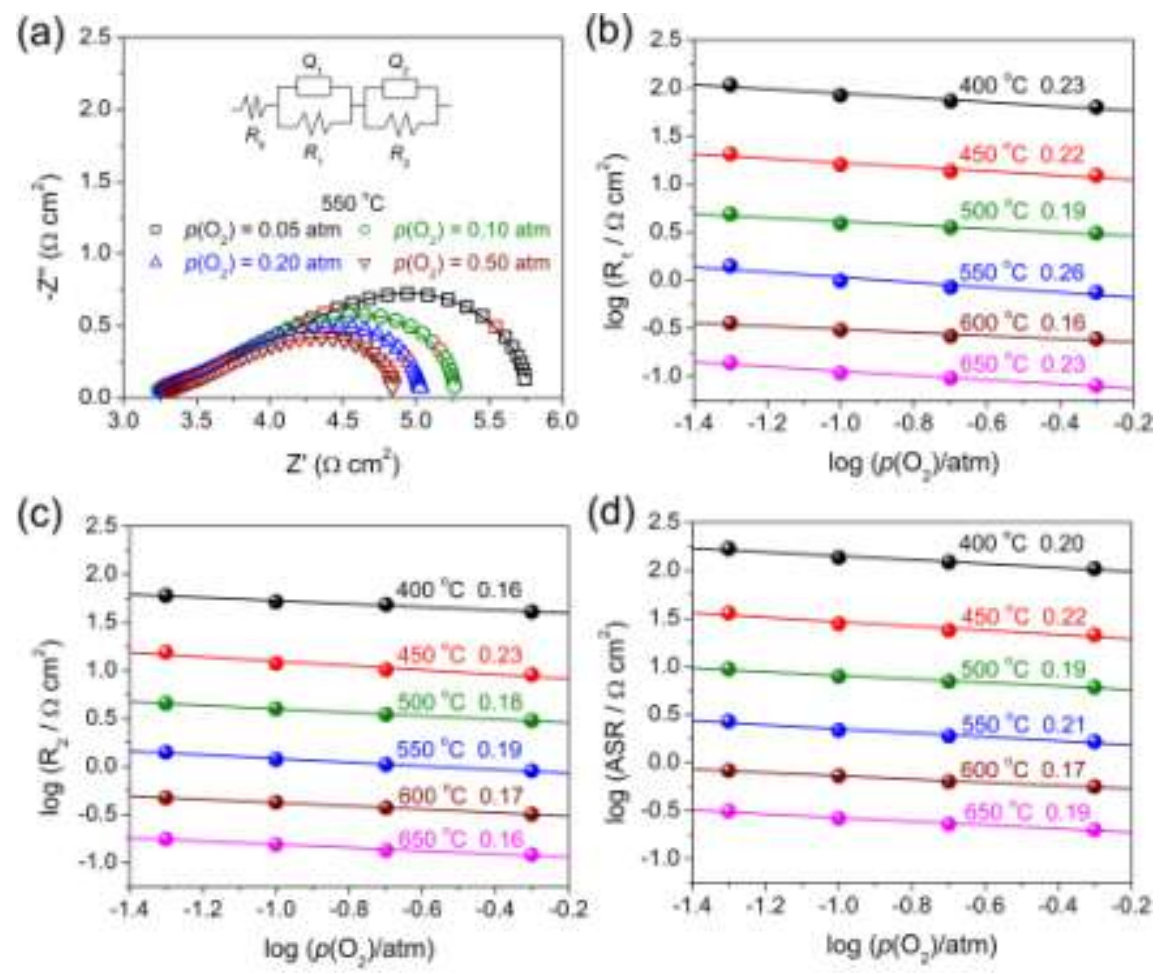

Fig. 3. (a) Impedance spectra of symmetrical cell LSM-BYC7/SCSZ/LSM-BYC7 at $550{ }^{\circ} \mathrm{C}$ along with the fitting results (solid lines). The characteristic frequencies (red symbols) from high to low are $10^{4}, 10^{3}, 10^{2}, 10^{1}, 10^{0}, 10^{-1}, 10^{-2} \mathrm{~Hz}$, respectively. The equivalent circuit is shown in the inset. Plots of (b)-(d) are the $p\left(\mathrm{O}_{2}\right)$ dependence of $\mathrm{R}_{1}, \mathrm{R}_{2}$, and ASR, respectively. The corresponding $\mathrm{m}$ values in $\mathrm{R}_{i}=K p\left(\mathrm{O}_{2}\right)^{-m_{i}}$ at different temperatures are inset.

As shown in Fig. $3 b$ and $c$, the $m$ values for the processes related to $R_{1}$ and $R_{2}$ are similar (0.16-0.26), varying between the theoretical values of 0.25 and 0.125 according to the model above. However, the $\mathrm{m}$ values associated with $\mathrm{R}_{1}$ is closer to 0.25 , i.e, the surface diffusion dominates the ORR kinetics whilst the charge transfer at the TPB dominates the process related to $\mathrm{R}_{2}$ because its $\mathrm{m}$ values are closer to 0.125 . Furthermore, the $\mathrm{C}$ values for the processes related to $\left(\mathrm{R}_{1} \mathrm{Q}_{1}\right)$ and $\left(\mathrm{R}_{2} \mathrm{Q}_{2}\right)$ are in the scale of $10^{-3}$ and $10^{-2} \mathrm{~F} \mathrm{~cm}^{-2}$; the apparent activation energy for $\mathrm{R}_{1}$ and $\mathrm{R}_{2}$ is 1.43 and $1.24 \mathrm{eV}$, respectively. Those values are similar to those reported for the processes related to surface diffusion and charge transfer processes of a cathode [22, 23, 43, 44]. A further analysis of ASR reveals that $\mathrm{R}_{1}$ dominates at temperatures $<500{ }^{\circ} \mathrm{C}$ whilst $\mathrm{R}_{2}$ at temperatures $\geq 500{ }^{\circ} \mathrm{C}$, which implies that the surface diffusion process becomes more facile 
with increasing temperatures so that the charge transfer at the TPBs becomes the RDS at higher temperatures. This result suggests that optimizing the component ratio and microstructure in the composite as a means of improving electronic conductivity can further enhance the ORR activity. Overall, the total ASR is primarily dominated by the processes related to both charge transfer and surface diffusion within the temperature range studied. The apparent $\mathrm{E}_{\mathrm{a}}$ for the total ASR is $1.34 \mathrm{eV}$, in agreement with the reported values for other $\mathrm{LSM}-\mathrm{Bi}_{2} \mathrm{O}_{3}$ composite cathodes (1.23$1.5 \mathrm{eV})[22-26]$.

The ASR of the LSM-BYC7 composite electrode on SCSZ electrolyte is compared with other types of composite cathodes in Fig. 4. LSM-BYC7 cathode exhibits the lowest ASR from 400 to $650{ }^{\circ} \mathrm{C}$ among others composite cathodes: LSM-ESB on GDC electrolyte [22], YSBimpregnated LSM on SDC electrolyte [25], and ESB-impregnated LSM on SCSZ electrolyte [26]. It should be noted that the ASR of screen-printed LSM-BYC7 prepared in this study is even lower than those $\mathrm{Bi}_{2} \mathrm{O}_{3}$-infiltrated LSM counterparts $[25,26]$. The higher ORR activity of the present LSM-BYC7 cathode is probably derived from its fine microstructure, where LSM and BYC7 powders were synthesized by citric acid-nitrate method. As will be discussed in Section 3.3, the LSM-BYC7 cathode is composed of larger BYC7 particles $(\sim 0.5 \mu \mathrm{m})$ surrounded by nano LSM particle $(<100 \mathrm{~nm})$. Both of them form continuous conduction paths, providing maximum TPBs and thus high ORR activity. Furthermore, compared with the LSM-GDC on GDC or YSZ electrolyte [18, 45], the present LSM-BYC7 on SCSZ shows 2-6× lower ASR at $600-650{ }^{\circ} \mathrm{C}$, which can be ascribed to the higher electrical conductivity of BYC7 [46]. 


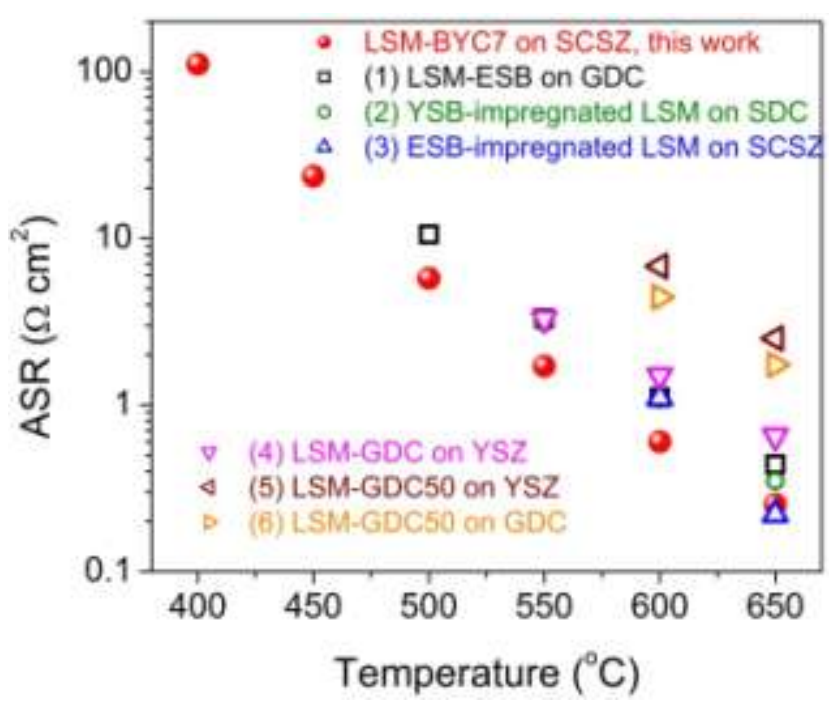

Fig. 4. Comparation of ASR of LSM-BYC7 with reported LSM-based composite cathode. (1) LSM ( $\left(\mathrm{La}_{0.8} \mathrm{Sr}_{0.2} \mathrm{MnO}_{3}\right)$-ESB $\left(\mathrm{Bi}_{1.6} \mathrm{Er}_{0.4} \mathrm{O}_{3}\right)$ on GDC [22], (2) YSB $\left(\mathrm{Bi}_{1.5} \mathrm{Y}_{0.5} \mathrm{O}_{3}\right)$-impregnated LSM $\left(\left(\mathrm{La}_{0.85} \mathrm{Sr}_{0.15}\right)_{0.9} \mathrm{MnO}_{3}\right)$ on SDC [25], (3) ESB $\left(\mathrm{Bi}_{1.6} \mathrm{Er}_{0.4} \mathrm{O}_{3}\right)$-impregnated LSM $\left(\mathrm{La}_{0.84} \mathrm{Sr}_{0.16} \mathrm{MnO}_{3}\right)$ on SCSZ $\quad\left(\left(\mathrm{ZrO}_{2}\right)_{0.89}\left(\mathrm{Sc}_{2} \mathrm{O}_{3}\right)_{0.1}\left(\mathrm{CeO}_{2}\right)_{0.01}\right) \quad$ [26], (4) LSM-GDC $\quad\left(\left(\mathrm{La}_{0.85} \mathrm{Sr}_{0.15}\right)_{0.9} \mathrm{MnO}_{3^{-}}\right.$ $\left.\mathrm{Ce}_{0.9} \mathrm{Gd}_{0.1} \mathrm{O}_{1.95}\right)$ on YSZ [45], (5) and (6) LSM-GDC50 $\left(\mathrm{La}_{0.8} \mathrm{Sr}_{0.2} \mathrm{MnO}_{3}-\mathrm{Ce}_{0.8} \mathrm{Gd}_{0.2} \mathrm{O}_{2-\delta}\right)$ on YSZ and GDC [18].

The ASR of LSM-BYC7 cathode on SDC and BYC7 electrolytes was also measured. The ASR on SDC was similar to that on SCSZ electrolyte, whereas it was decreased by $\sim 50 \%$ on BYC7 electrolyte, i.e., 3.15, 0.78, 0.32, and $0.13 \Omega \mathrm{cm}^{2}$ at 500, 550, 600, and $650{ }^{\circ} \mathrm{C}$, respectively. A lower ASR of LSM-ESB cathode on ESB electrolyte than on GDC electrolyte was also observed by Lee et al. [22], which is probably associated with the improved oxygen incorporation rate at the interface between LSM-BYC7 cathode and BYC7 electrolyte.

The long-term ASR stability of LSM-BYC7 electrode on SCSZ electrolyte in symmetrical cell was examined at $500{ }^{\circ} \mathrm{C}$; the result is shown in Fig. 5a. The ASR shows no measurable degradation, stable around $6.0 \Omega \mathrm{cm}^{2}$ over $100 \mathrm{~h}$. An XRD analysis shown in Fig. 5b on LSMBYC7 annealed at a similar condition shows no sign of interdiffusion between LSM and BYC7. Overall, there exists a good chemcial compatibility between LSM and BYC7. Together with the structural stability of BYC7, the stable ASR observed in Fig. 5a is thus understandable. 

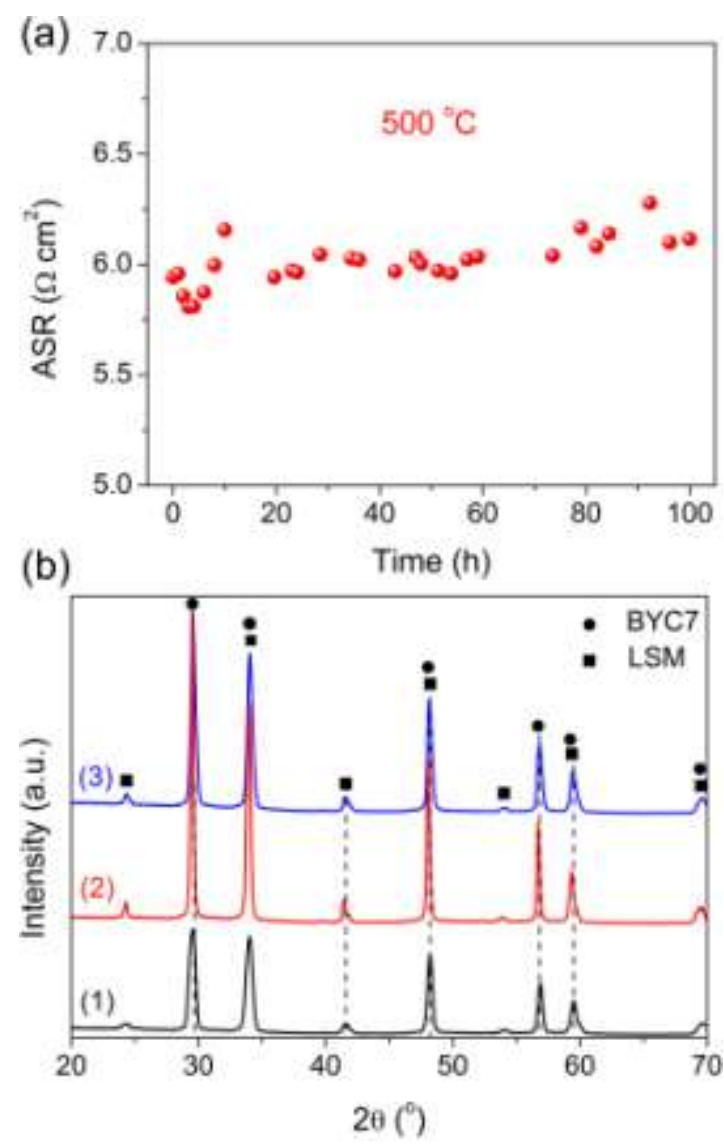

Fig. 5. (a) Evolution of LSM-BYC7 electrode polarition resistance with time at $500{ }^{\circ} \mathrm{C}$ over 100 h. (b) XRD patterns of (1) fresh pellet of mixed LSM-BYC7, (2) sample (1) anealed at $800{ }^{\circ} \mathrm{C}$ for $2 \mathrm{~h}$, (3) sample (2) annealed at $500{ }^{\circ} \mathrm{C}$ for $100 \mathrm{~h}$ in air.

\subsection{Microstructure and electrochemical performance of single SOFC}

The microstructure of the anode-supported SOFC is depicted in Fig. 6, where the thickness of anode, electrolyte, and cathode is roughly 370, 30-35, and $15 \mu \mathrm{m}$, respectively. The SCSZ electrolyte is dense except minor closed pores. Both anode and cathode are porous in microstructure and have good bonding with the electrolyte. 

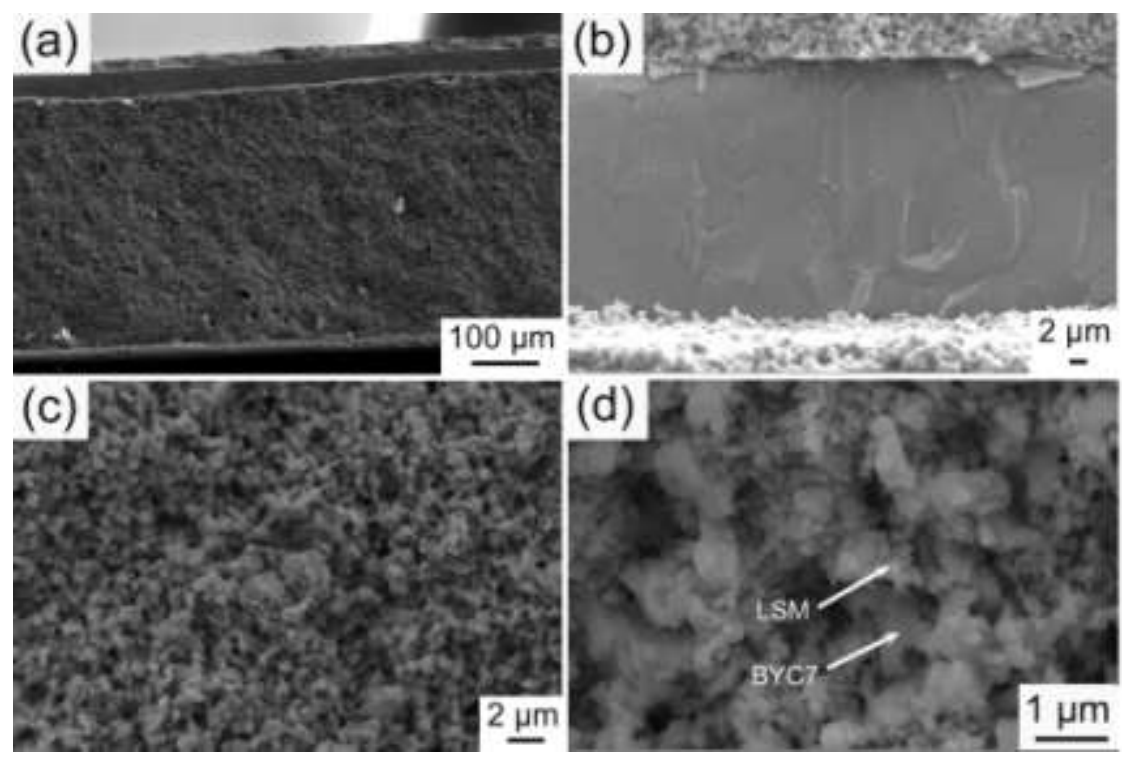

Fig. 6. (a) SEM overview of the anode-supported SOFC, microstructure of (b) electrolyte, (c) anode and (d) cathode after test.

The performance of LSM-BYC7 cathode was evaluated in a single button cell. The currentvoltage and current-power curves are shown in Fig. 7a. The cell open circuit voltage at 500, 550, 600 , and $650{ }^{\circ} \mathrm{C}$ is $1.151,1.141,1.135$, and $1.128 \mathrm{~V}$, respectively, very close to the theoretical values of $1.152,1.144,1.136$, and $1.128 \mathrm{~V}$, indicating that the electrolyte is dense enough and the glass sealing works reasonably well. The corresponding maximum power density (MPD) is $56.4,154.5,327.9$, and $451.0 \mathrm{~mW} \mathrm{~cm}^{-2}$ at $500,550,600$, and $650{ }^{\circ} \mathrm{C}$, respectively. Concentration polarization appears at high current density at $600{ }^{\circ} \mathrm{C}$, which is more pronounced at $650{ }^{\circ} \mathrm{C}$. Such high concentration polarization is closely related to gas diffusion in the electrodes, which will be discussed below. The performance as shown in Fig. 7b of the present anode-supported SOFC with the LSM-BYC7 composite cathode prepared by simple screen-printing method is comparable or even better than that reported ones with impregnated cathodes [23, 24, 26, 47]. The results again suggest a higher electrocatalytic activity of LSM-BYC7 towards ORR. Although the MPD presented here is lower than that reported of SOFCs based on electrolyets GDC, SDC, GDC/ESB bilayer, LSGM [3, 11, 13], issues with those electrolytes such as 
electronic conduction, cost, mechanical strength, as mentioned in the Introduction, prevent them from being practically employed.
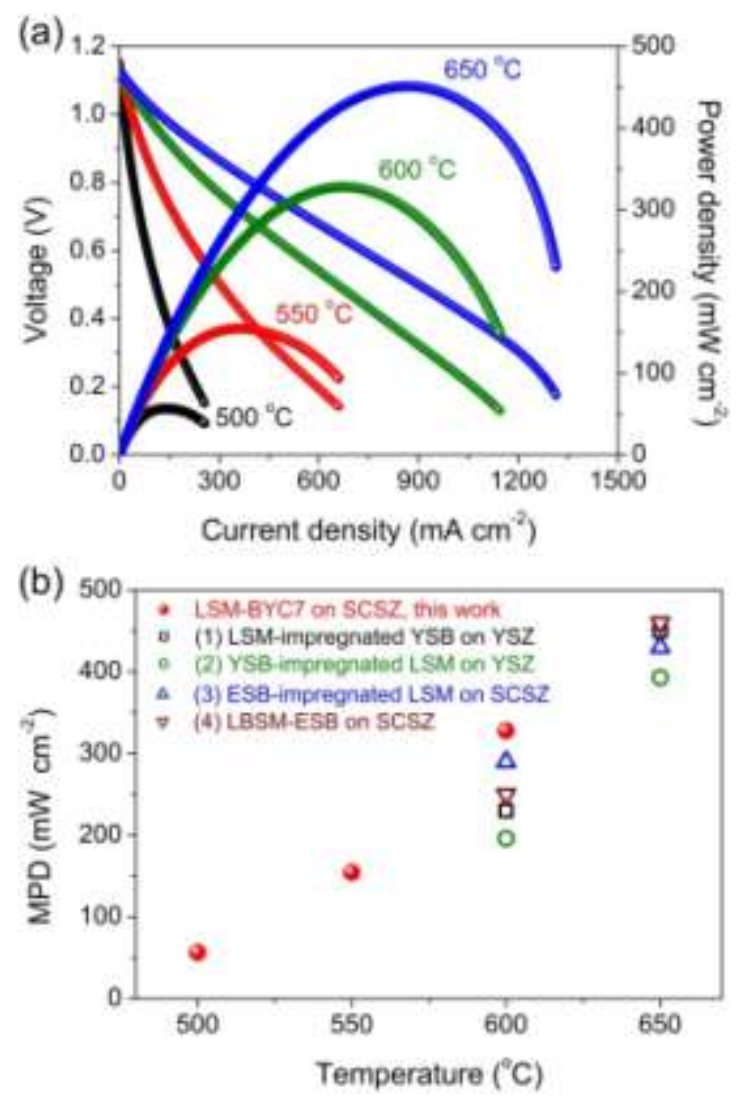

Fig. 7. (a) Current-voltage and current-power curves for anode-supported SOFC with $\mathrm{H}_{2} / 3 \% \mathrm{H}_{2} \mathrm{O}$ as fuel and stagnant laboratory air as oxidant. (b) Comparison of maximum power density (MPD) of SOFCs with LSM- $\mathrm{Bi}_{2} \mathrm{O}_{3}$-based cathodes on doped zirconia electrolytes at temperatures of 500-650 ${ }^{\circ} \mathrm{C}$. (1) LSM (( $\left.\left.\mathrm{La}_{0.85} \mathrm{Sr}_{0.15}\right)_{0.9} \mathrm{MnO}_{3}\right)$-impregnated YSB $\left(\mathrm{Bi}_{1.5} \mathrm{Y}_{0.5} \mathrm{O}_{3}\right)$ on YSZ [23], (2) YSB $\left(\mathrm{Bi}_{1.5} \mathrm{Y}_{0.5} \mathrm{O}_{3}\right)$-impregnated LSM $\left(\left(\mathrm{La}_{0.85} \mathrm{Sr}_{0.15}\right)_{0.9} \mathrm{MnO}_{3}\right)$ on $10 \mu \mathrm{m}$-thick YSZ [24], (3) ESB $\left(\mathrm{Bi}_{1.6} \mathrm{Er}_{0.4} \mathrm{O}_{3}\right)$-impregnated $\mathrm{LSM} \quad\left(\mathrm{La}_{0.84} \mathrm{Sr}_{0.16} \mathrm{MnO}_{3}\right) \quad$ on $15 \quad \mu$-thick SCSZ $\left(\left(\mathrm{ZrO}_{2}\right)_{0.89}\left(\mathrm{Sc}_{2} \mathrm{O}_{3}\right)_{0.1}\left(\mathrm{CeO}_{2}\right)_{0.01}\right)$ [26], (4) LBSM $\left(\mathrm{La}_{0.74} \mathrm{Bi}_{0.10} \mathrm{Sr0}{ }_{.16} \mathrm{MnO}_{3}\right)-\mathrm{ESB}\left(\mathrm{Bi}_{1.4} \mathrm{Er}_{0.6} \mathrm{O}_{3}\right)$ on $15 \mu$ m-thick SCSZ [47].

The impedance spectra of the single cell at $500-650{ }^{\circ} \mathrm{C}$ are displayed in Fig. 8a. Two semicircles are noticeable at $500{ }^{\circ} \mathrm{C}$ and a third one evolves at low frequencies with increasing temperature. To determine the nature of each semicircle, anode-supported single SOFCs with the same cathode but different anodes, i.e. Ni-SCSZ anode sintered at different temperatures and with different content of pore formers, were prepared and tested. The results (not shown here) 
indicate that the semi-circle at high frequencies (e.g., $>10 \mathrm{~Hz}$ at $500{ }^{\circ} \mathrm{C}$ ) is very sensitive to the microstructural changes of the anode, whereas the processes at intermediate frequencies remain unchanged. This observation agrees with the previous reports in which the high frequency arc is generally assigned to anode [48-50]. The process at the low frequencies changes with hydrogen and air flow rates and the corresponding fitted capacitance is higher than $1 \mathrm{~F} \mathrm{~cm}^{-2}$, implying that it is likely associated with gas diffusion in the electrodes. Overall, the high-frequency process can be assigned to the electrochemical processes at the anode, intermediate-frequency process to the electrochemical processes at the cathode, and low-frequency process to non-electrochemical process (gas diffusion) in the anode and cathode.

As shown in Fig. 8a, the ohmic resistance, anode and cathode polarization resistance decrease with temperature, but the anode polarization resistance dominates the total cell electrode polarization loss $\left(\mathrm{R}_{\mathrm{p}}\right)$, which is the summation of anode $\left(\mathrm{R}_{\text {anode }}\right)$ and cathode $\left(\mathrm{R}_{\text {cathode }}\right)$ electrochemical polarization resistance and gas diffusion resistance (not shown separately). Generally, the cathode performance is deemed the limiting factor for IT-SOFCs. However, the present study shows that the anode can also be the performance determining factor [50-52]. As a thick substrate shown in Fig. 6c, the anode's high tortuosity could limit gas diffusion, resulting in high concentration polarization as shown in Fig. 7a, particularly at higher temperatures where activation polarization is significantly reduced. Therefore, designing a microstructure of the anode to facilitate the mass transport while still maintaining sufficient TPBs at the electrolyte/electrode interface is a key to enhance the performance of IT-SOFCs. 

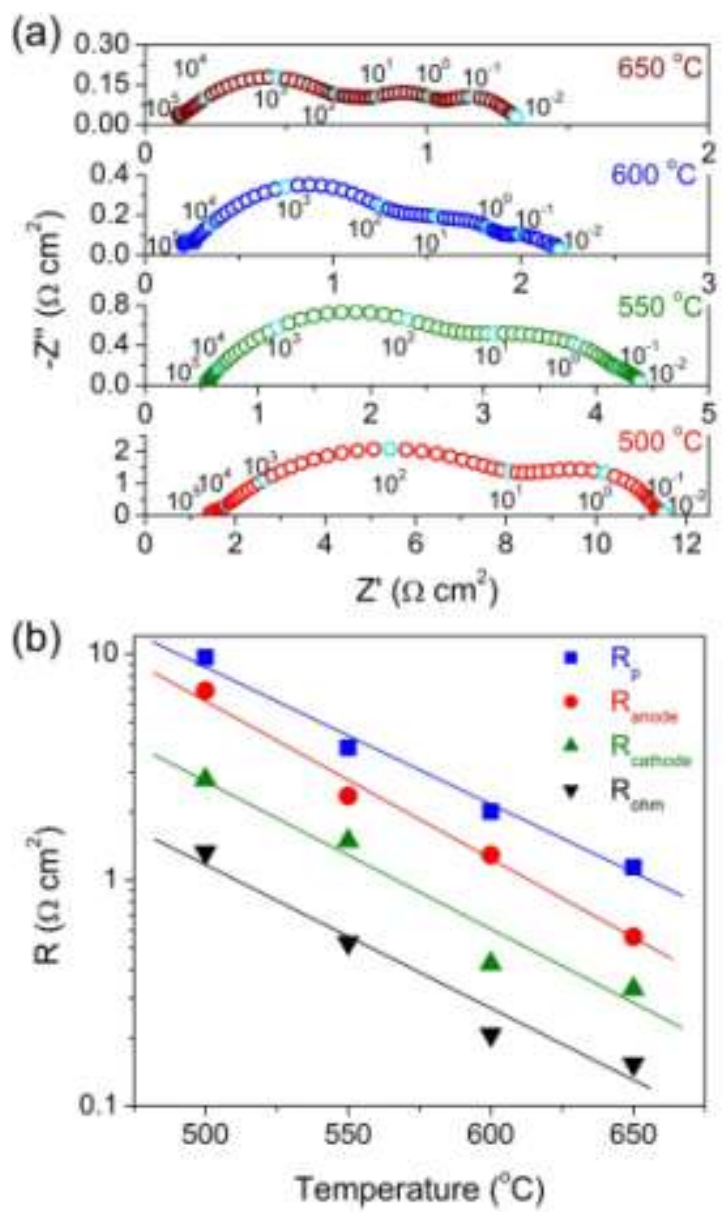

Fig. 8. (a) AC-impedance spectra of anode-supported SOFC at open circuit condition, (b) evolution of ohmic resistance $\left(R_{\text {ohm }}\right)$, anode $\left(R_{\text {anode }}\right)$, cathode $\left(R_{\text {cathode }}\right)$ and total electrode $\left(R_{p}\right)$ polarization resistance with temperature.

It is noteworthy that the cathode polarization resistance in single SOFC is smaller compared to the ASR measured from symmetrical cell (Fig. 4), e.g., $2.78 \Omega \mathrm{cm}^{2}$ in single cell vs. $5.76 \Omega$ $\mathrm{cm}^{2}$ in symmetrical cell at $500{ }^{\circ} \mathrm{C}$. This observation infers that the cathode electrocatalytic activity towards the ORR is improved under electrical loading [43]. In addition, Fig. 8b shows that the ohmic resistance is much lower than the total electrode polarization by about one order of magnitude. The anode and cathode polarization resistances are the dominant components in the total cell resistance. Therefore, reducing electrode polarization resistance is the most effective way to improve the performance of IT-SOFCs. 


\section{Conclusions}

The present work reports a new composite cathode comprising a mixture of electronic conductor LSM and ionic conductor $\mathrm{Y}$ - and Ce- co-doped $\mathrm{Bi}_{2} \mathrm{O}_{3}$ (BYC7). BYC7 shows a high and stable electrical conductivity at low temperatures, which ensures a high and stable ORR activity of the composite cathode with fine microstructure. The polarization resistance of screenprinted LSM-BYC7 cathode in a symmetrical cell is 5.76, 1.71, 0.60, and $0.25 \Omega \mathrm{cm}^{2}$ at 500, 550, 600 , and $650{ }^{\circ} \mathrm{C}$, respectively. The surface diffusion and charge transfer processes are the rate determining steps for the ORR. The maximum power density of anode-supported SOFC with NiSCSZ anode, SCSZ electrolyte, and LSM-BYC7 cathode is 56.4, 154.5, 327.9, and $451.0 \mathrm{~mW}$ $\mathrm{cm}^{-2}$ at 500, 550, 600, and $650{ }^{\circ} \mathrm{C}$, respectively. The anode, rather than the cathode, is the performance limiting factor of single cell operated in the temperature range of $500-650{ }^{\circ} \mathrm{C}$. Further microstructural optimization of the anode substrate to minimize the gas diffusion resistance while maintaining sufficient TPBs at the electrolyte/anode interface could hold a key to improve the performance. Overall, this study shows that LSM-BYC7 is a promising composite cathode material for IT-SOFCs.

\section{Acknowledgements}

This work was funded by the Advanced Research Projects Agency-Energy (ARPA-E), U.S. Department of Energy, under Award number DE-AR0000492.

\section{References}

[1] N.Q. Minh, J. Am. Cer. Soc. 76 (1993) 563-588.

[2] D.J.L. Brett, A. Atkinson, N.P. Brandon, S.J. Skinner, Chem. Soc. Rev. 37 (2008) 1568-1578.

[3] E.D. Wachsman, K.T. Lee, Science 334 (2011) 935-939. 
[4] J.B. Goodenough, Annu. Rev. Mater. Res. 33 (2003) 91-128.

[5] V.V. Kharton, F.M.B. Marques, A. Atkinson, Solid State Ionics 174 (2004) 135-149.

[6] T. Ishihara, H. Matsuda, Y. Takita, J. Am. Chem. Soc. 116 (1994) 3801-3803.

[7] K. Huang, R.S. Tichy, J.B. Goodenough, J. Am. Ceram. Soc. 81 (1998) 2565-2575.

[8] D.S. Lee, W.S. Kim, S.H. Choi, J. Kim, H.W. Lee, J.H. Lee, Solid State Ionics 176 (2005) 33-39.

[9] A. Orera, P.R. Slater, Chem. Mater. 22 (2010) 675-690.

[10] A.J. Jacobson, Chem. Mater. 22 (2010) 660-674.

[11] Z. Shao, S.M. Haile, Nature 431 (2004) 170-173.

[12] K. Huang, J.-H. Wan, J.B. Goodenough, J. Electrochem. Soc. 148 (2001) A788-A794.

[13] Z. Zhan, D.M. Bierschenk, J.S. Cronin, S.A. Barnett, Energy Environ. Sci. 4 (2011) 39513954.

[14] A. Mai, V.A.C. Haanappel, S. Uhlenbruck, F. Tietz, D. Stöver, Solid State Ionics 176 (2005) $1341-1350$.

[15] Z. Duan, M. Yang, A. Yan, Z. Hou, Y. Dong, Y. Chong, M. Cheng, W. Yang, J. Power Sources 160 (2006) 57-64.

[16] J.H. Kim, M. Cassidy, J.T.S. Irvine, J. Bae, Chem. Mater. 22 (2010) 883-892.

[17] S.P. Jiang, J. Mater. Sci. 43 (2008) 6799-6833.

[18] E. Perry Murray, S.A. Barnett, Solid State Ionics 143 (2001) 265-273.

[19] B.C.H. Steele, Solid State Ionics 75 (1995) 157-165.

[20] T. Takahashi, H. Iwahara, Mater. Res. Bull. 13 (1978) 1447-1453.

[21] N. Jiang, E.D. Wachsman, S.-H. Jung, Solid State Ionics 150 (2002) 347-353. 
[22] K.T. Lee, D.W. Jung, H.S. Yoon, A.A. Lidie, M.A. Camaratta, E.D. Wachsman, J. Power Sources 220 (2012) 324-330.

[23] Z. Jiang, Z. Lei, B. Ding, C. Xia, F. Zhao, F. Chen, Inter. J. Hydrogen Energy 35 (2010) 8322-8330.

[24] Z. Jiang, L. Zhang, L. Cai, C. Xia, Electrochim. Acta 54 (2009) 3059-3065.

[25] Z. Jiang, L. Zhang, K. Feng, C. Xia, J. Power Sources 185 (2008) 40-48.

[26] J. Li, S. Wang, Z. Wang, R. Liu, T. Wen, Z. Wen, J. Power Sources 194 (2009) 625-630.

[27] J. Li, S. Wang, Z. Wang, R. Liu, T. Wen, Z. Wen, J. Power Sources 179 (2008) 474-480.

[28] J. Li, S. Wang, Z. Wang, R. Liu, X. Ye, X. Sun, T. Wen, Z. Wen, J. Power Sources 188 (2009) 453-457.

[29] J. Hou, L. Bi, J. Qian, Z. Zhu, J. Zhang, W. Liu, J. Mater. Chem. A 3 (2015) 10219-10224.

[30] N. Jiang, E.D. Wachsman, J. Am. Ceram. Soc. 82 (1999) 3057-3064.

[31] D.W. Jung, K.L. Duncan, M.A. Camaratta, K.T. Lee, J.C. Nino, E.D. Wachsman, J. Am. Ceram. Soc. 93 (2010) 1384-1391.

[32] K. Huang, M. Feng, J.B. Goodenough, Solid State Ionics 89 (1996) 17-24.

[33] N. Jiang, R.M. Buchanan, F.E.G. Henn, A.F. Marshall, D.A. Stevenson, E.D. Wachsman, Mater. Res. Bull. 29 (1994) 247-254.

[34] N. Jiang, R.M. Buchanan, D.A. Stevenson, W.D. Nix, J.-Z. Li, J.-L. Yang, Mater. Lett. 22 (1995) 215-219.

[35] C. Zhang, K. Huang, ACS Energy Lett. 1 (2016) 1206-1211.

[36] J. Rodríguez-Carvajal, Phys. B: Cond. Matt. 192 (1993) 55-69.

[37] D.W. Jung, K.L. Duncan, E.D. Wachsman, Acta Mater. 58 (2010) 355-363. 
[38] E.D. Wachsman, S. Boyapati, M.J. Kaufman, N. Jiang, J. Am. Ceram. Soc. 83 (2000) 19641968.

[39] T. Takeda, R. Kanno, Y. Kawamoto, Y. Takeda, O. Yamamoto, J. Electrochem. Soc. 147 (2000) 1730-1733.

[40] A. Jaiswal, E.D. Wachsman, J. Electrochem. Soc. 152 (2005) A787-A790.

[41] F.H. van Heuveln, H.J.M. Bouwmeester, J. Electrochem. Soc. 144 (1997) 134-140.

[42] J. Fleig, Solid State Ionics 150 (2002) 181-193.

[43] D. Chen, R. Ran, K. Zhang, J. Wang, Z. Shao, J. Power Sources 188 (2009) 96-105.

[44] J.-D. Kim, G.-D. Kim, J.-W. Moon, Y.-i. Park, W.-H. Lee, K. Kobayashi, M. Nagai, C.-E. Kim, Solid State Ionics 143 (2001) 379-389.

[45] C. Xia, Y. Zhang, M. Liu, Electrochem. Solid-State Lett. 6 (2003) A290-A292.

[46] C.W. Tanner, K.Z. Fung, A.V. Virkar, J. Electrochem. Soc. 144 (1997) 21-30.

[47] J. Li, S. wang, Z. Wang, J. Qian, R. Liu, T. Wen, Z. Wen, J. Solid State Electrochem. 14 (2010) 579-583.

[48] J.-H. Koh, Y.-S. Yoo, J.-W. Park, H.C. Lim, Solid State Ionics 149 (2002) 157-166.

[49] M. Brown, S. Primdahl, M. Mogensen, J. Electrochem.Soc. 147 (2000) 475-485.

[50] Y. Lin, Z. Zhan, J. Liu, S.A. Barnett, Solid State Ionics 176 (2005) 1827-1835.

[51] H. Huang, J. Lin, Y. Wang, S. Wang, C. Xia, C. Chen, J. Power Sources 274 (2015) 11141117.

[52] F. Zhao, A.V. Virkar, J. Power Sources 141 (2005) 79-95. 


\section{Figure captions}

Fig. 1. XRD patterns and corresponding Rietveld refinement results of (a) BYC7 $\left(\mathrm{R}_{\mathrm{p}}=8.67 \%\right.$, $\mathrm{R}_{\mathrm{wp}}=8.23 \%$, ) and (b) ESB $\left(\mathrm{R}_{\mathrm{p}}=10.2 \%, \mathrm{R}_{\mathrm{wp}}=9.75 \%\right)$.

Fig. 2. (a) Arrhenius plot of electrical conductivity of BYC7 and ESB in air with Pt as current collector. (b) Evolution of electrical conductivity of BYC7 and ESB with time at $500{ }^{\circ} \mathrm{C}$ in air with Pt as current collector. (c) XRD of (1) sample holder for XRD test, (2) $900{ }^{\circ} \mathrm{C}-0.5 \mathrm{~h}$ calcined BYC7 pellet with Pt paste on both sides, (3) BYC7 samples annealed at $500{ }^{\circ} \mathrm{C}$ for 100 $\mathrm{h}$ in air, (4) BYC7 and (5) ESB pellets after electrical conductivity test at $500{ }^{\circ} \mathrm{C}$ for $100 \mathrm{~h}$ with $\mathrm{Pt}$ as current collector.

Fig. 3. (a) Impedance spectra of symmetrical cell LSM-BYC7/SCSZ/LSM-BYC7 at $550{ }^{\circ} \mathrm{C}$ along with the fitting results (solid lines). The characteristic frequencies (red symbols) from high to low are $10^{4}, 10^{3}, 10^{2}, 10^{1}, 10^{0}, 10^{-1}, 10^{-2} \mathrm{~Hz}$, respectively. The equivalent circuit is shown in the inset. Plots of (b)-(d) are the $p\left(\mathrm{O}_{2}\right)$ dependence of $\mathrm{R}_{1}, \mathrm{R}_{2}$, and ASR, respectively. The corresponding $\mathrm{m}$ values in $\mathrm{R}_{i}=K p\left(\mathrm{O}_{2}\right)^{-m_{i}}$ at different temperatures are inset.

Fig. 4. Comparation of ASR of LSM-BYC7 with reported LSM-based composite cathode. (1) $\mathrm{LSM}\left(\mathrm{La}_{0.8} \mathrm{Sr}_{0.2} \mathrm{MnO}_{3}\right)$-ESB $\left(\mathrm{Bi}_{1.6} \mathrm{Er}_{0.4} \mathrm{O}_{3}\right)$ on GDC [22], (2) YSB $\left(\mathrm{Bi}_{1.5} \mathrm{Y}_{0.5} \mathrm{O}_{3}\right)$-impregnated LSM $\left(\left(\mathrm{La}_{0.85} \mathrm{Sr}_{0.15}\right)_{0.9} \mathrm{MnO}_{3}\right)$ on SDC [25], (3) ESB $\left(\mathrm{Bi}_{1.6} \mathrm{Er}_{0.4} \mathrm{O}_{3}\right)$-impregnated LSM $\left(\mathrm{La}_{0.84} \mathrm{Sr}_{0.16} \mathrm{MnO}_{3}\right)$ on $\mathrm{SCSZ} \quad\left(\left(\mathrm{ZrO}_{2}\right)_{0.89}\left(\mathrm{Sc}_{2} \mathrm{O}_{3}\right)_{0.1}\left(\mathrm{CeO}_{2}\right)_{0.01}\right) \quad$ [26], (4) LSM-GDC $\quad\left(\left(\mathrm{La}_{0.85} \mathrm{Sr}_{0.15}\right)_{0.9} \mathrm{MnO}_{3^{-}}\right.$ $\left.\mathrm{Ce}_{0.9} \mathrm{Gd}_{0.1} \mathrm{O}_{1.95}\right)$ on YSZ [45], (5) and (6) LSM-GDC50 $\left(\mathrm{La}_{0.8} \mathrm{Sr}_{0.2} \mathrm{MnO}_{3}-\mathrm{Ce}_{0.8} \mathrm{Gd}_{0.2} \mathrm{O}_{2-\delta}\right)$ on YSZ and GDC [18].

Fig. 5. (a) Evolution of LSM-BYC7 electrode polarition resistance with time at $500{ }^{\circ} \mathrm{C}$ over 100 h. (b) XRD patterns of (1) fresh pellet of mixed LSM-BYC7, (2) sample (1) anealed at $800{ }^{\circ} \mathrm{C}$ for $2 \mathrm{~h}$, (3) sample (2) annealed at $500{ }^{\circ} \mathrm{C}$ for $100 \mathrm{~h}$ in air.

Fig. 6. (a) SEM overview of the anode-supported SOFC, microstructure of (b) electrolyte, (c) anode and (d) cathode after test.

Fig. 7. (a) Current-voltage and current-power curves for anode-supported $\mathrm{SOFC}$ with $\mathrm{H}_{2} / 3 \% \mathrm{H}_{2} \mathrm{O}$ as fuel and stagnant laboratory air as oxidant. (b) Comparison of maximum power density (MPD) of SOFCs with LSM- $\mathrm{Bi}_{2} \mathrm{O}_{3}$-based cathodes on doped zirconia electrolytes at temperatures of 500-650 ${ }^{\circ} \mathrm{C}$. (1) LSM (( $\left.\left.\mathrm{La}_{0.85} \mathrm{Sr}_{0.15}\right)_{0.9} \mathrm{MnO}_{3}\right)$-impregnated $\mathrm{YSB}\left(\mathrm{Bi}_{1.5} \mathrm{Y}_{0.5} \mathrm{O}_{3}\right)$ on YSZ [23], (2) YSB $\left(\mathrm{Bi}_{1.5} \mathrm{Y}_{0.5} \mathrm{O}_{3}\right)$-impregnated LSM $\left(\left(\mathrm{La}_{0.85} \mathrm{Sr}_{0.15}\right)_{0.9} \mathrm{MnO}_{3}\right)$ on $10 \mu \mathrm{m}$-thick YSZ [24], (3) ESB $\left(\mathrm{Bi}_{1.6} \mathrm{Er}_{0.4} \mathrm{O}_{3}\right)$-impregnated LSM $\left(\mathrm{La}_{0.84} \mathrm{Sr}_{0.16} \mathrm{MnO}_{3}\right) \quad$ on $15 \quad \mu$-thick SCSZ $\left(\left(\mathrm{ZrO}_{2}\right)_{0.89}\left(\mathrm{Sc}_{2} \mathrm{O}_{3}\right)_{0.1}\left(\mathrm{CeO}_{2}\right)_{0.01}\right)$ [26], (4) LBSM $\left(\mathrm{La}_{0.74} \mathrm{Bi}_{0.10} \mathrm{SrO}_{.16} \mathrm{MnO}_{3}\right)-\mathrm{ESB}\left(\mathrm{Bi}_{1.4} \mathrm{Er}_{0.6} \mathrm{O}_{3}\right)$ on $15 \mu \mathrm{m}$-thick SCSZ[47].

Fig. 8. (a) AC-impedance spectra of anode-supported SOFC at open circuit condition, (b) evolution of ohmic resistance $\left(R_{\text {ohm }}\right)$, anode $\left(R_{\text {anode }}\right)$, cathode $\left(R_{\text {cathode }}\right)$ and total electrode $\left(R_{p}\right)$ polarization resistance with temperature. 